Original Article

\title{
Gastroesophageal tube of the Iguana iguana (Iguanidae): histological description, histochemical and immunohistochemical analysis of 5-HT and SS cells
}

\author{
Tubo gastroesofágico da Iguana iguana (Iguanidae): descrição histológica, histoquímica \\ e análise imunohistoquímica de células 5-HT e SS
}

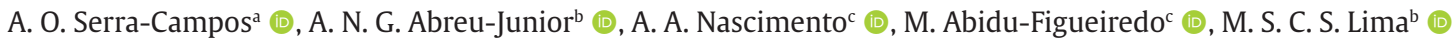 \\ and C. Machado-Santos ${ }^{\text {a* }}$ (i) \\ aUniversidade Federal Fluminense - UFF, Departamento de Morfologia, Laboratório de Ensino e Pesquisa em Histologia e Embriologia \\ Comparada - LEPHEC, Niterói, RJ, Brasil \\ bUniversidade Federal do Piauí - UFPI, Departamento de Biologia, Laboratório de Herpertologia, Floriano, PI, Brasil \\ 'Universidade Federal Rural do Rio de Janeiro - UFRRJ, Instituto de Ciências Biológicas e da Saúde, Programa de Pós-graduação em Biologia \\ Animal, Seropédica, RJ, Brasil
}

\begin{abstract}
The work aims were to describe the histological and histochemical structure of the gastroesophageal tube of Iguana iguana and verify the occurrence and distribution of immunoreactive serotonin (5-HT) and somatostatin (SS) cells. Fragments of the gastrointestinal tract (GIT) of five iguanas were which underwent standard histological and immunohistochemistry technique. Immunoreactive cells for 5-HT and SS were quantified using the STEPanizer. The oesophagus has ciliated columnar pseudostratified epithelium with staining Alcian blue (AB) + and goblet cells highly reactive to periodic acid Schiff (PAS). In the cervical oesophagus, the numerical density of 5-HT cells per unit area ( $\mathrm{QA}\left[5-\mathrm{HT}\right.$ cells] $/ \mu^{2}$ ) was $4.6 \times 10^{-2} \pm 2.0$ and celomatic oesophagus presented $\mathrm{QA}=4.0 \times 10^{-2} \pm 1.0$. The epithelium of the stomach is simple columnar, PAS and $\mathrm{AB}+$. The cranial and middle regions of the stomach presented $\left(\mathrm{QA}[5-\mathrm{HT}\right.$ cells $\left.] / \mu^{2}\right)=6.18 \times 10^{-2} \pm 3.2$ and the caudal region, $\mathrm{QA}=0.6 \times 10^{-2} \pm 0.2$. The SS cells were only observed in the caudal stomach, with numerical density (QA [SS cells] $/ \mu \mathrm{m}^{2}$ ) $=1.4 \times 10^{-2} \pm 0.9$ In $I$. iguana, variation was observed in terms of the distribution of mucus secretions and the pattern of occurrence of serotonin and somatostatin-secreting enteroendocrine cells in the TGI, which possibly will result in an interspecific adaptive response.
\end{abstract}

Keywords: serotonin, somatostatin, stomach-oesophagus, morphology, reptilian.

\begin{abstract}
Resumo
Os objetivos do trabalho foram descrever a estrutura histológica e histoquímica do tubo gastroesofágico da Iguana iguana e verificar a ocorrência e distribuição de células serotonina (5-HT) e somatostatina (SS) imunorreativas. Fragmentos do trato gastrointestinal (TGI) de cinco iguanas foram submetidos à técnica histológica e imunohistoquímica padrão. As células imunorreativas para 5-HT e SS foram quantificadas usando o STEPanizer. O esôfago apresenta epitélio pseudoestratificado colunar ciliado Alcian blue (AB) positivo, com células caliciformes altamente reativas ao ácido periódico de Schiff (PAS). No esôfago cervical, a densidade numérica de células 5-HT por unidade de área $\left(\mathrm{QA}\right.$ [células $5-\mathrm{HT}$ ] $/ \mu^{2}$ ) foi de $4.6 \times 10^{-2} \pm 2.0$ e o esôfago celomático apresentou $\mathrm{QA}=4.0 \times 10^{-2} \pm 1.0$. $O$ epitélio do estômago é colunar simples, PAS e AB positivo. As regiões cranial e média do estômago apresentaram $(\mathrm{QA}$ [células $\left.5-\mathrm{HT}] / \mu \mathrm{m}^{2}\right)=6.18 \times 10^{-2} \pm 3.2$ e a região caudal, $\mathrm{QA}=0.6 \times 10^{-2} \pm 0.2$. As células $\mathrm{SS}$ foram observadas apenas no estômago caudal, com densidade numérica (QA [células SS] $/ \mu \mathrm{m}^{2}$ ) $=1.4 \times 10^{-2} \pm 0.9$. Em I. iguana, foi observada variações em termos da distribuição das secreções de muco e padrão de ocorrência das células enteroendócrinas secretoras de serotonina e somatostatina no TGI, o que possivelmente reflete uma resposta adaptativa interespecifica.
\end{abstract}

Palavras-chave: serotonina, somatostatina, estômago-esôfago, morfologia, réptil.

*e-mail: claricemachado@id.uff.br

Received: September 15, 2020 - Accepted: January 12, 2021 


\section{Introduction}

The green iguana belongs to the order of Squamata, which is considered one of the most diverse among vertebrates, with 10,857 species (Uetz et al., 2020). Its Iguanidae family holds more than 45 species (Uetz et al., 2020), but the genus Iguana is comprised of only three species: Iguana iguana (Linnaeus, 1758), widely distributed throughout Latin America, Iguana delicatissima (Laurenti, 1768), restricted to the Lesser Antilles, and the one recently described Iguana melanoderma (Breuil et al., 2020), endemic to the islands of Saba and Montserrat. The common green iguana is heliothermal arboreal and primarily herbivorous and consumes animal protein in the form of snails and insects that occur, probably incidentally, on the surrounding vegetation, thus they are considered a polyspecific herbivore (Hirth, 1963; Lara-López and Gonzáles-Romero, 2002; Townsend et al., 2005; Teles et al., 2017).

The green iguanas are originated from central and south America. They are considered an invasive species due to inadvertent movement of wild individuals or the release of captive animals (Falcón et al., 2013; Kubiak, 2019; Spinner, 2018). In Brazil, consumption of meat and eggs of the green iguana is a possible source of food for a few rural communities, which together with the illegal capture of wild populations for the illicit supply of the international domestic animal market can be a great threat to the species. It is worth mentioning that all Iguana spp. are listed in Appendix II of the Convention on International Trade in Endangered Species of Wild Fauna and Flora (CITES), resulting in restrictions on trade of wild individuals (Kubiak, 2019; Spinner, 2018). The green iguana is already endangered in Costa Rica and Panamá (Andrade, 2009).

Morphological studies on the structure of the digestive tract are essential to understand the vertebrate lifestyle as well as physiological aspects. Studies on the reptilian gastrointestinal tract (GIT) have been performed using histochemical techniques showing histological peculiarities in the oesophagus and stomach (Loo and Wong, 1975; Rovira et al., 1993; Bani et al., 1992).

About 3\% of the lizards are herbivores (King, 1996) belonging mainly to the families Iguanidae (e.g, Green iguana) and Agamidae (e.g, Uromastyx) (O’Malley, 2005). The oesophagus of a lizard has thin walls that enters the stomach through the left antimere of the abdomen. Unlike that observed in other reptiles, such as snakes, this is short and has a temporary food storage capacity (Zug et al., 2001; O’Malley, 2005).

The herbivores reptiles generally have larger stomach than carnivores (Pianka and Vitt, 2003) however, the digestive efficiency is lower (King, 1996). This is due to the fact that foods of plant origin are digested with more difficulty than those of animal origin (Ricklefs, 2003), and also, because reptiles do not ferment food during night cooling, since low temperatures slow down gastrointestinal motility and secretion of digestive juices (Troyer, 1984; O'Malley, 2005). Therefore, the stomach can function as a reservoir or fermentation chamber, allowing the absorption of digestible proteins and nutrients (O'Malley, 2005).

Enteroendocrine cells (EECs) represent the largest population of endocrine cells in the body. Many EECs subtypes have been described in vertebrates, each characterized by the secretion of a distinct hormone (Schonhoff et al., 2004; Santos et al., 2008; Ryu et al., 2018). EECs that produce peptides that regulate motility such as serotonin and somatostatin are more frequent in the GIT than endocrine cells that produce peptides regulating digestion (Solcia et al., 1975). Lee and Ku, 2004, demonstrated that more serotonin- and somatostatinpositive cells were found in the GIT of the grass lizard than cells positive for digestion-regulating peptides. Beside this, EECs have been reported in the GIT of Squamata's species: the Grass lizard, Mabuya quinquetaeniata (El-Salhy and Grimelius, 1981), King's skink, Egernia kingii (Arena et al., 1990), Ocellated skink, Chalcides ocellatus (Virgilio et al., 2004) and the Tiger keelback snake, Rhabdophis tigrinus tigrinus (Lee et al., 1999). More than fifteen regulatory peptides were found in the GIT of these lizards. Because of the strategic evolutionary position, information on the EECs of the reptilian digestive tract is important.

As there are few studies of the biology, habitat requirements and of the Iguana iguana utilization in Brazil, histological knowledge about the GIT of reptiles is an essential tool for an understanding of their biology as well as a prerequisite for the implementation of conservation and management projects. In light of this, the work aims were to describe the histological and histochemical structure of the gastroesophageal tube in I. iguana and verify the occurrence and distribution of serotonin and somatostatin secretory cells through a specific immunohistochemical method, providing data on the enteroendocrine cells of this species for comparative purposes with other reptiles.

\section{Material and Methods}

\subsection{Tissue preparation and staining}

Five green iguanas, three males and two female freeliving were collected in Barão de Grajaú-MA, caatinga region, and they were deposited in the Natural History Collection of the Federal University of Piauí with authorization SISBIO 54501-2. The GIT fragments were donated to the Laboratory of Teaching and Research in Histology and Compared Embryology at UFF. The GIT Fragments were fixed in $10 \%$ buffered formaldehyde and were processed according to the standard histological techniques for paraffin embedding. Five micrometers thick histological serial sections were deparaffinized in xylene, after gradually hydrated through graded alcohols followed by distilled water and stained with hematoxylineosin (HE) and Gomori's trichrome method (GT) (Lillie and Fullmer, 1976). Staining with Alcian blue (AB) 8GX at pH 2.5 (Kiernan, 1990) was employed for the demonstration of sulfated and carboxylated acidic glycoconjugates. The periodic acid Schiff (PAS) staining was employed to detect neutral glycoconjugates.

\subsection{Immunohistochemistry}

After deparaffinization and hydration, the sections were incubated by $3 \%$ hydrogen peroxide in phosphate 
buffered saline (PBS, pH 7.2) for 30 minutes to block endogenous peroxidase. Antigen retrieval was performed by immersing the sections in citrate buffer at $\mathrm{pH}$ 6.0, in a water bath at $96{ }^{\circ} \mathrm{C}$ for $45 \mathrm{~min}$. Sections were incubated with goat serum 10\% (EP-12-20531- Easypath) in humid chamber during 10 minutes at room temperature for Blocking of the non-specific reaction. They were then incubated overnight at $4^{\circ} \mathrm{C}$ with rabbit polyclonal antiserotonin (S 5545 - Sigma-Aldrich, inc.) 1:8000 and antisomatostatin (A0566, Dako) diluted to 1:300. Afterwards, rinsing in a PBS, the sections were incubated with polymer Envision DuoFLEX Doublestain System (SK11021) for 30 minutes. Subsequently, the reaction was revealed by with 3, 3'-diaminobenzidine tetrahydrochloride (DAB) (Dakocytomation 003222) and sections were counterstained with Harris hematoxylin.

Digital images of the histological sections were obtained at 40 and 20x magnification using Aperio CS $^{\text {TM }}$ scanner (Leica Biosystems, USA).

\subsubsection{5-HT and SS quantification}

Ten random microscopic fields were analyzed per animal on a light microscope DM 500 and a Leica ICC50 HD camera. Digital images were taken in 40X objective magnification. The numerical density per area of 5-HT and SS cells was evaluated considering the number of cells into a frame of known area produced with the STEPanizer webbased system (www.stepanizer.com) (Tschanz et al., 2011 ), totaling and area of $\approx 3.39 \times 10^{2} \mu \mathrm{m}^{2} /$ animal. The 5 -HT and SS cells were counted into the frame when they did not hit the "forbidden lines" or its extensions (Gundersen,
1977). The frequency of occurrence is expressed as mean $+/$ - SD (standard deviation) per unit area $\left(1 \mu \mathrm{m}^{2}\right)$.

\section{Results}

\subsection{Light microscopy}

The oesophagus of the I. iguana presents a tubular form and is divided into two regions: cervical and celomatic, evidenced by the increase in folds in the region close to the stomach (Figure 1). The stomach is divided into three: cranial, middle and caudal (Figure 1). The esophageal mucosa protrudes into the lumen through longitudinal folds that vary in size. In the stomach there are also longitudinal folds that vary in size depending on the degree of repletion of the organ.

In the oesophagus the lining is composed of ciliated columnar pseudostratified epithelium with $A B$ positive goblet cells (Figure 2b), and moderate PAS for columnar cells and strongly PAS positive for goblet cells (Figure 2a). The lamina propria consists of loose connective tissue and no mucous glands were observed (Figure 3). Below the, lamina propria is a muscularis mucosa, consisted of bundles of smooth muscle fibers in longitudinal direction in the cervical oesophagus (Figure 3), but circular in the celomatic region.

The submucosa was formed by collagenous fibers without glands (Figure 3).

In the cervical oesophagus, the muscular layer has bundles of smooth muscle fibers in two directions: inner

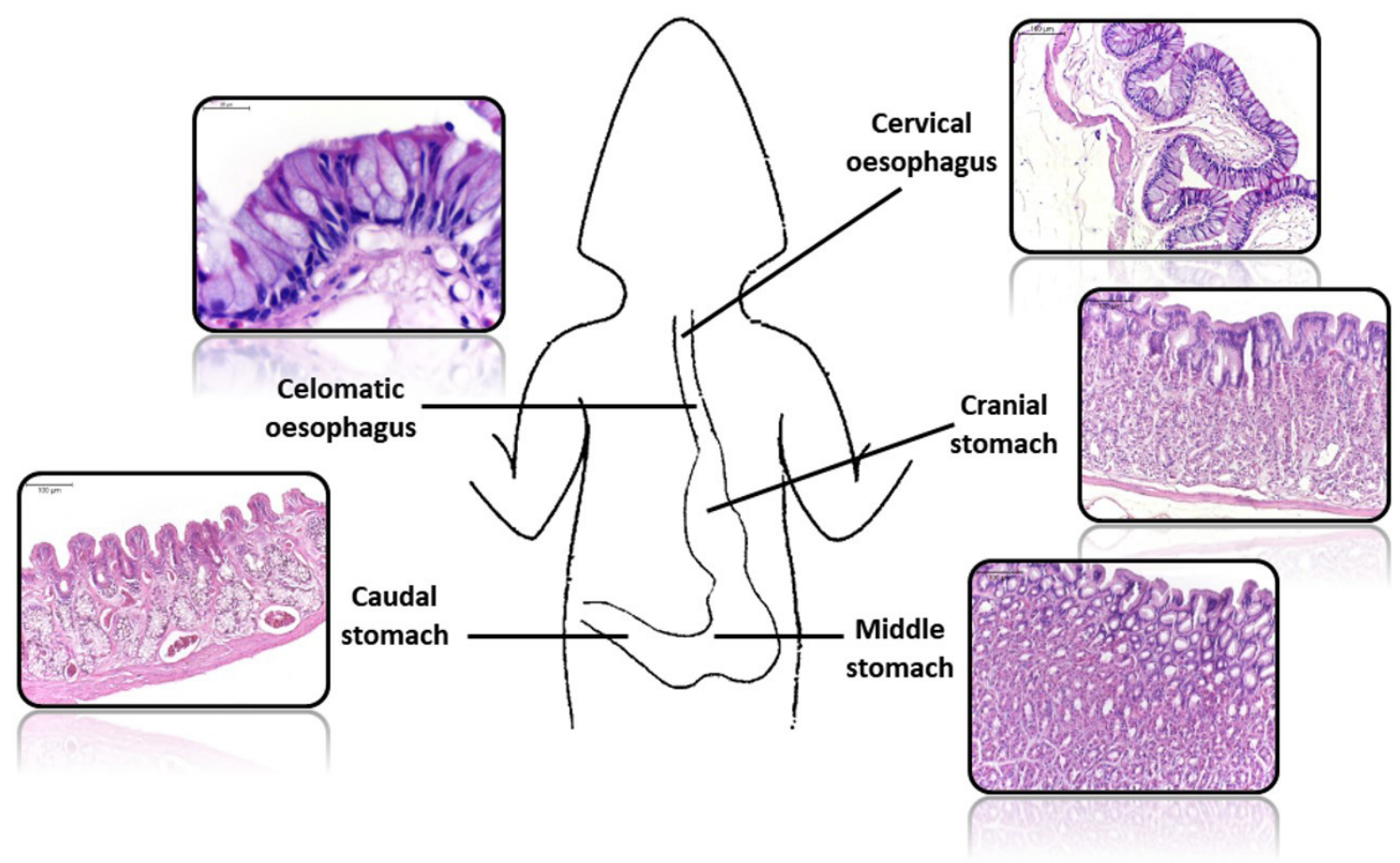

Figure 1. Histological sections of the mucosa layer of I. iguana in different regions of the oesophagus and stomach. HE. Bars $=100 \mu \mathrm{m}$. Caudal eosophagus $20 \mu \mathrm{m}$. 

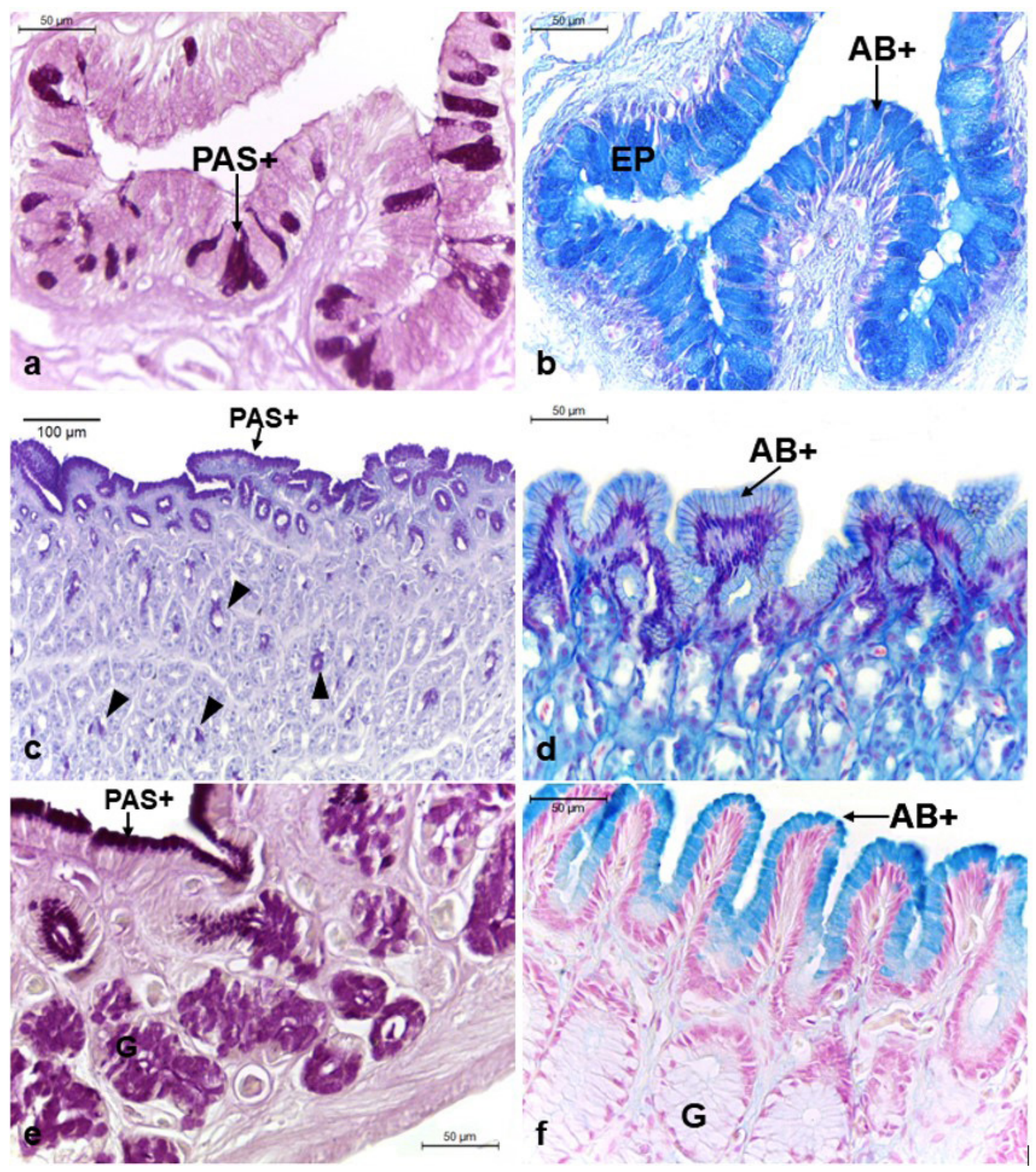

Figure 2. Histological sections of the (a,b) oesophagus, (c) cranial, (d) middle and (e-f) caudal regions of stomach of I. iguana. (a) After Periodic Acid Schiff (PAS) staining the glycoconjugates are identified in magenta in the goblet cells (arrow) in oesophagus; (b) The ephitelium (EP) of oesophagus has positive histochemical reaction to Alcian Blue ( $\mathrm{AB}, \mathrm{pH} 2.5$ ); (c-f) The epithelium lining of stomach is simple columnar mucous with positive histochemical reactions to PAS (c,e) and AB (d,f). (c) Note the mucous cells PAS-positive along the glands (arrowhead) in cranial region of stomach; (e) In caudal region gastric glands (G) are positive only for PAS reaction.

circular and outer longitudinal (Figure 3), which becomes outer circular and inner longitudinal in the celomatic region.

The adventitial layer is formed by loose connective tissue with the presence of blood vessels and nerves (Figure 3 ).

The mucosa layer throughout the entire stomach has a simple columnar mucous epithelium (Figure 4 and 5 - detail) with strong PAS (Figure 2c, e) and AB positivity
(Figure 2d, f). This epithelium invaginates to form the gastric pits (Figure 4 and 5).

The lamina propria, a region formed of loose connective tissue and blood vessels, has an abundance of simple tubular gastric glands (Figure 5). When comparing the cranial and middle regions, similarity was observed, except for the presence of more abundant connective 


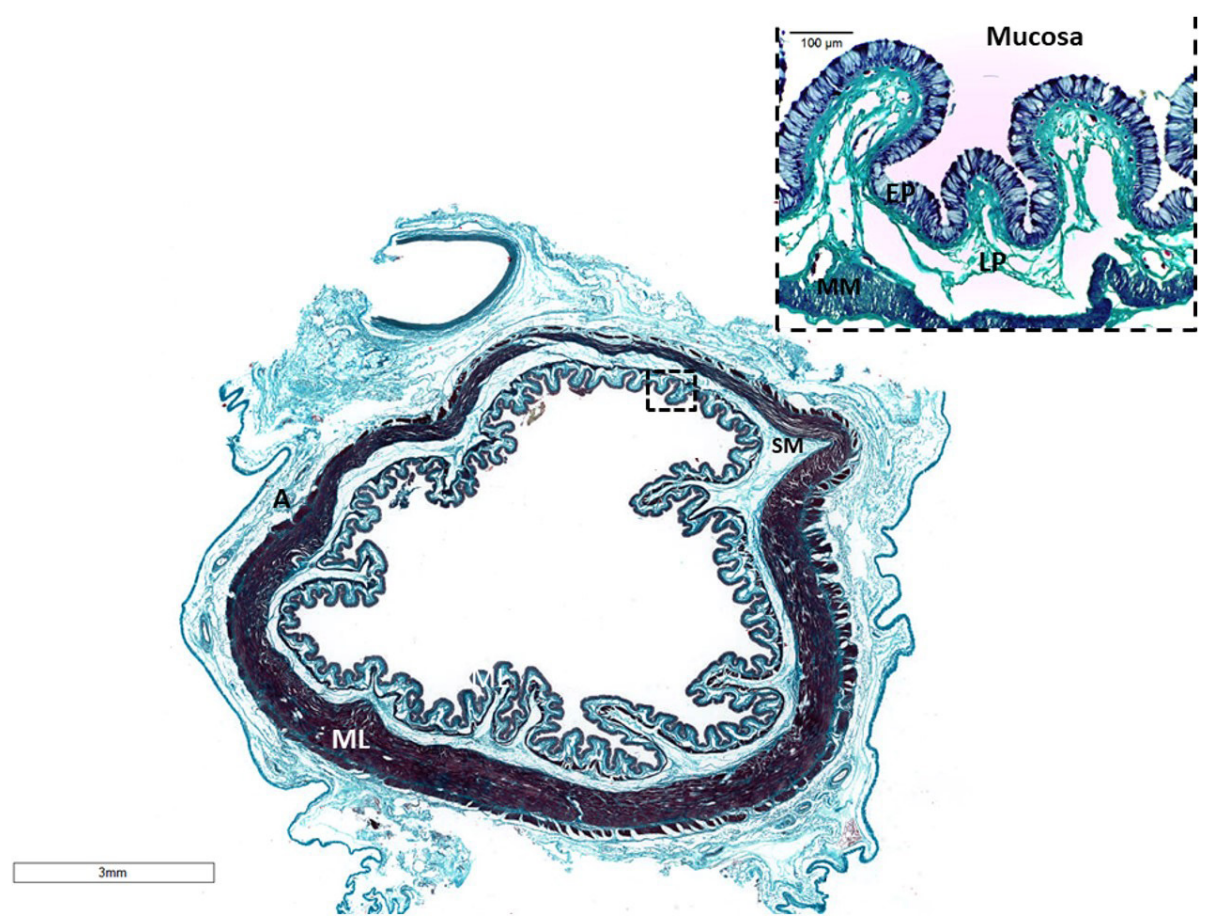

Figure 3. Histological sections of cervical oesophagus of I. iguana. Observe longitudinal folds. Absence of glands in the lamina propria (LP) and submucosa (SM), and evident muscular layer (ML) and adventitia (A). Bars $=3 \mathrm{~mm}$. Detail of mucous layer with epithelium (EP), lamina propria (LP) and muscularis mucosa (MM). Gomori’s tricrome staining.

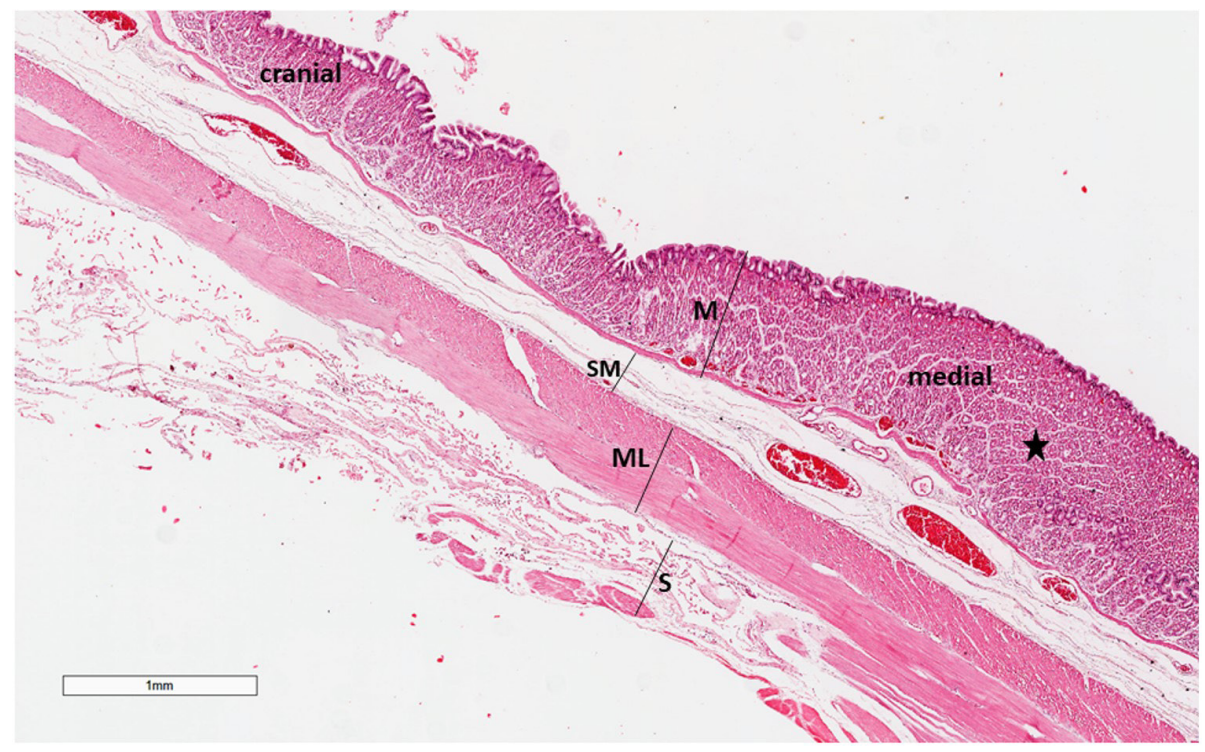

Figure 4. Histological sections of cranial and middle region in stomach. Note the gastric glands are more developed in the middle region, occupying a large part of the lamina propria (star). M: mucosa, SM: submucosa, ML: muscular layer and S: serosa. HE staining.

tissue in the cranial region and more developed glands in the middle region, occupying a large part of the lamina propria (Figure 4). These glands have a predominance of oxynticopeptic cells that were AB and PAS negative. PASpositive mucous cells are also noticed along the gland (Figure 2c). The caudal portion presents a decrease in the size of these glands, which show predominantly mucous cells, PAS-positive (Figure 2e), but they are less reactive when compared to those of the lining epithelium, and weakly stained in $\mathrm{AB}$ (Figure 2f).

The muscularis mucosa, which is below the lamina propria, consists of bundles of smooth muscle fibers in two directions: internal circular and external longitudinal (Figure 4 and 5). 
The submucosa layer is composed of loose connective tissue richly vascularized (Figure 4 and 5).

The cranial and middle stomach muscular layer has bundles of smooth muscle fibers in two directions: internal circular and external longitudinal (Figure 4), while the caudal region consists of only one layer of smooth fibers oriented circularly and notably thicker (Figure 5).
The stomach is covered by a serous membrane which is quite evident in the caudal region (Figure 5).

\subsection{Immunohistochemistry}

5 -HT cells were observed in all portions of the oesophagus and stomach of the I. iguana (Figure 6). In the oesophagus, 5-HT positive cells were located at the

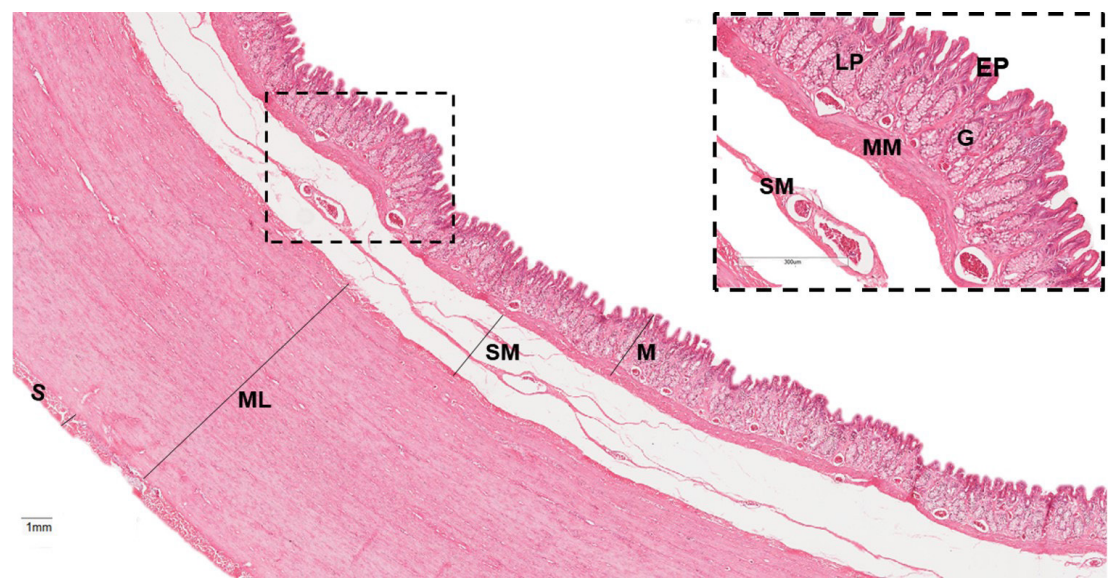

Figure 5. Histological sections of caudal region in stomach. The epithelium lining (EP) is simple columnar with gastric glands (G) in the lamina propria (LP). M: mucosa. Note the thickening of the muscular layer (ML) and the presence of serosa (S). Detail of mucous layer with epithelium (EP), lamina propria (LP), gastric glans (G), muscularis mucosa (MM) and submucosa (SM). HE staining. Bars $=300 \mu \mathrm{m}$.

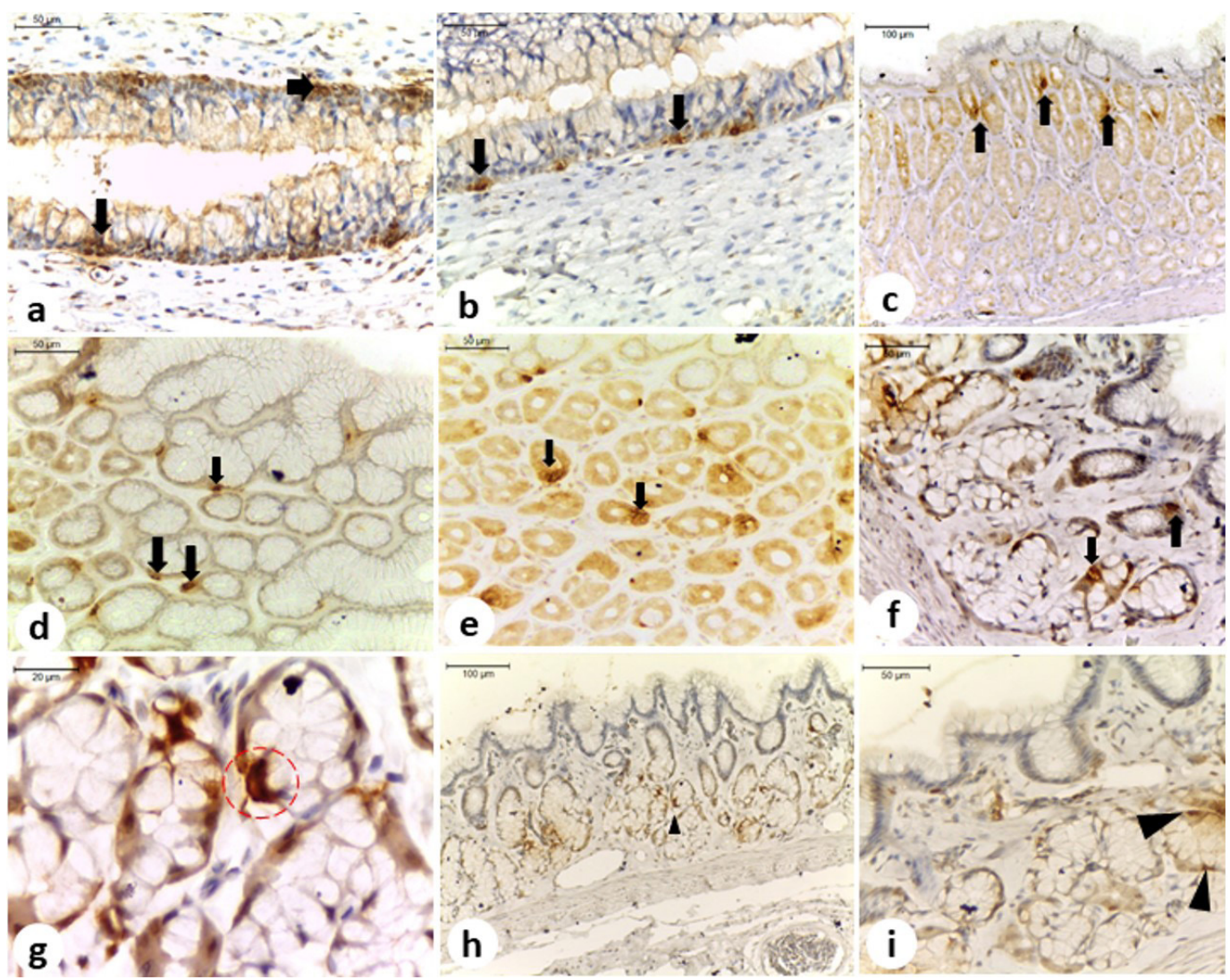

Figure 6. Immunoreactivity for Serotonin (5-HT) a-g and Somatostatin (SS) i-h in histological sections of the oesophagus (a,b), cranial stomach (c), middle stomach (d,e) and caudal stomach (f-i) of I. iguana. a-g Serotonin-positive cells (arrow). h,i Somatostatin-positive cells (arrowhead) in the caudal region of the stomach. 


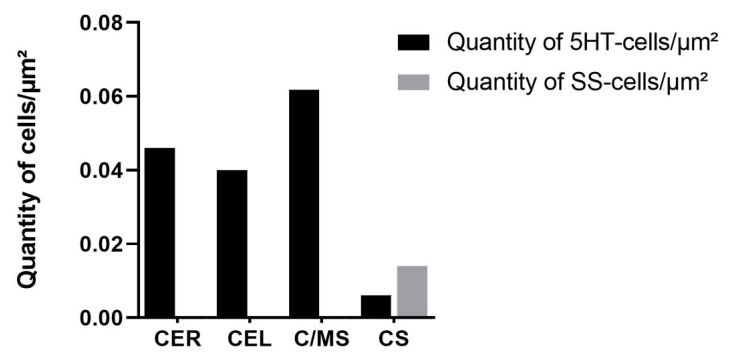

Graph 1. Number of 5 -HT and SS-cells $/ \mu \mathrm{m}^{2}$ per oesophageal and gastric region in I. iguana. Values are averages with their standard deviatin shown by vertical bars $(p=0,05)$. Cervical oesophagus (CER): $4.6 \times 10^{-2} \pm 2.0$ [5-HT cells] $/ \mu^{2} \mathrm{~m}^{2}$. Celomatic oesophagus (CEL): $4.0 \times 10^{-2} \pm 1.0[5-\mathrm{HT}$ cells $] / \mu^{2}$. Cranial and middle regions of the stomach (C/MS): $6.18 \times 10^{-2} \pm 3.2$ [5-HT cells] $/ \mu^{2}$. Caudal Stomach (CS): $0.6 \times 10^{-2} \pm 0.2\left[5\right.$-HT cells] $/ \mu \mathrm{m}^{2}$ and $1.4 \times 10^{-2} \pm 0.9$ [SS-cells] $/ \mu^{2}$.

base of the epithelium (Figure 6a, b). In the cervical oesophagus the numerical density of 5-HT cells per unit area (QA [5-HT cells] $/ \mu \mathrm{m}^{2}$ ) was $4.6 \times 10^{-2} \pm 2$ (Graph 1 ) and celomatic oesophagus $\mathrm{QA}=4.0 \times 10^{-2} \pm 1.0$ (Graph 1$)$. While in the stomach, they are also found in the gastric glands beyond the epithelium, mainly in the apex in the cranial (Figure $6 c$ ) and middle (Figure $5 d$, e) regions of the stomach: QA [5-HT cells] $/ \mu \mathrm{m}^{2}=6.18 \times 10^{-2} \pm 3.2($ Graph 1$)$. In the caudal part of the stomach, the marking occurs along the entire gland without a specific pattern (Figure 6f, g), with $\mathrm{QA}=0.6 \times 10^{-2} \pm 0.2$ (Graph 1 ). The 5 -HT cells observed were the "closed type" ones without visible cytoplasmic process. The markings found on the connective tissue of the lamina propria are possibly mast cells.

Somatostatin secretory cells were only observed in the caudal region near the intestine (Figure 6h, i). These cells occupy the glandular area and were not seen in the lining epithelium, being the QA [SS cells] $/ \mu^{2}=1.4 \times 10^{-2}$ \pm 0.9 (Graph 1 ). They are "closed type", with no evident cytoplasmic process.

\section{Discussion}

The oesophagus is a slender tube that expands easily to accommodate even a large bolus of food (Kardong, 2018). The oesophagus of the I. iguana were divided into cervical and celomatic, evidenced by the increase in folds in the region close to the stomach.

According to George and Castro (1998) and Elliott (2007), the esophageal mucosa of reptiles, in general, is lined by epithelium with one or two layers of columnar cells. In Squamata's, of different genus as I. iguana, Hemidactylus mabouia (Rodrigues-Sartori et al., 2011) and E. kingii (Arena et al., 1990), the esophageal epithelium is usually ciliated and pseudostratified with goblet cells, although a simple columnar epithelium has been observed in other genus such as snake Enhydris enhydris (Masyitha et al., 2020), in the chameleon Chamaeleon africanus (Hamdi et al., 2014) and in the lizards Laudakia stellio (Koca and Gürcü, 2011) and Varanus niloticus (Ahmed et al., 2009). Thus, there is no phylogenetic relationship that explains the change in the type of esophageal epithelium between different species, which may be better associated with variations in eating habits.

The ciliary propulsion can help gather small crumbs from the meal and move these along to the stomach, facilizing swallowing as well as cleaning the esophageal covering. Moreover, the ciliated cells it controls the flow of lubricating mucus around the food to aid in the passage (Kardong, 2018).

The absence of oesophageal glands in the lamina propria and submucosa layer, described in I. iguana and Uromastyx aegyptiaca (herbivouous) (Zaher et al., 2012), H. mabouia (feeds on a wide variety of arthropods) (RodriguesSartori et al., 2015) and Caiman latirostris (carnivorous) (Machado-Santos et al., 2011), can be correlated with the rapid transit of food to the stomach, with no involvement of the oesophagus in the digestion. However, when the oesophageal glands are present, these, play some role in digestion. Such as the branched tubular glands in L. stellio (Koca and Gürcü, 2011) that secrete mucins neutrals and acids, especially acidic mucins, which are important for lubrication of the mucosa and allow the passage of food particles, similar to what occurs in C. africanus (Hamdi et al., 2014), since are both insectivorous. So, there is no relationship between the systematic position of the animal and the presence or absence of such glands.

The muscularis mucosa of the oesophagus is absent in many species of reptiles (Elliott, 2007). However, it is present in the species of suborder Iguania, e.g: I. iguana (in this study), C. africanus (Hamdi et al., 2014), U. aegyptiaca (Zaher et al., 2012) and L. stellio (Koca and Gürcü, 2011). The movement of the muscularis mucosa is related to the secretion and absorption of the esophageal glands, however, as these glands are absent in I. iguana, their presence can be related to the secretion of the epithelial secretory cells.

The oesophagus of the green iguana presented a welldeveloped muscularis wall formed of smooth muscle fibers in two directions: inner circular and outer longitudinal in the cervical oesophagus, and inner longitudinal and outer circular in the celomatic region. Which may help in performing the function of mechanical conveyance and in food swallowing. However, the amount of muscle in the esophageal wall varies among the main groups of reptiles (Elliott, 2007).

In reptiles the stomach varies in shape (Elliott, 2007). In the Squamata order, the anatomy of the stomach can be of saccular type as in distant families of lizards: Ophisops elegans (Çakici and Akat, 2013) and V. niloticus (Ahmed et al., 2009), or tubular in the shape of a 'J' in the lizards of the Gekkonidae family H. mabouia (Rodrigues-Sartori et al., 2011) and Cyrtodactylus peguensis (Thongboon et al., 2019), considered carnivores, or can present a 'U'-shaped stomach as seen in I. iguana, a mainly herbivorous animal.

Usually, the stomach of the reptiles can be distinguished into two regions: fundus and pylorus, according to the characteristics of the present glands (Luppa, 1977). However, the stomach of I. iguana was distinguished into three regions: cranial, middle and caudal as previously described by Smith and collaborators in their study using radiography (Smith et al., 2001). 
The simple columnar mucous epithelium is indicative of the stomach, as soon as in all reptiles. This mucus secretion plays important roles, including the protection of underlying epithelium from mechanical and chemical stress, electrolyte absorption, increasing digestive efficiency and lubrication of tract (Gupta, 1989; Allen and Snary, 1972).

In some groups of reptiles, the glandular region contains two cell types: oxynticopeptic cells and mucous cells (Kardong, 2018). The ratios of the two cell types vary among stomach regions and among species (George and Castro, 1998; Arena et al., 1990; Ferri et al., 1999; Kardong, 2018). In the cranial and middle stomach of I. iguana, oxynticopeptics cells are the predominant. These cells produce both hydrochloric acid $(\mathrm{HCl})$ and pepsinogen (Arena et al., 1990; Ferri et al., 1999). In the lizard Chalcides chalcides the oxynticopeptics cells show different cytological features. In the oral fundic mucosa these cells, show a cytoplasm filled with granules, characteristic of protein secreting cells and in the aboral fundic region, the oxynticopeptic cells, are typical of the mammalian parietal acid-secreting cells, suggesting a secretion gradient of proteolytic enzymes and perhaps hydrochloric acid along the proximodistal axis of the stomach (Ferri et al.,1999).

The neutral glycoconjugates shown by the PAS method, have a protective function against mechanical injuries, pathogens and pepsin (Ferri et al., 2001). In the oesophagus of I. iguana, as well as the $H$. mabouia (Rodrigues-Sartori et al., 2015) the goblet cells were AB and PAS-positive. And in the stomach the gastric glands exhibit a positive reaction only with PAS, as also observed in the lizards C. peguensis (Thongboon et al., 2019), C. africanus (Hamdi et al., 2014), O. elegans (Çakici and Akat, 2013).

However, the gastric epithelium of I. iguana revealed strong reactivity to $\mathrm{AB}$, similar to that observed in the lizards U. aegyptiaca (Zaher et al., 2012) and L. stellio (Koca and Gürcü, 2011), all belonging to suborder Iguania. Bearing in mind that the acid glycoconjugates shown by the $A B$ method can be responsible for an increasing viscosity of the gastric secretions (Díaz et al., 2008), facilitating the movement of the bolus through the stomach (Ahmed et al., 2009). In addition, Dehlawi and Zaher (1985), in their studies with Acanthodactylus Boskianus, suggested that the gastric glands of this lizard might be the source of acid mucopolysaccharides.

The presence of a relatively thick gastric muscularis layer, as described in I. iguana, initiate the first major digestive breakdown of food through strong muscular contraction (Elliott, 2007). Besides that, the gastric transit time is influenced by a variety of intrinsic and extrinsic factors and can vary from 3 to 6 days in carnivorous lizards, compared to 15-30 days in herbivorous lizards (Smith et al., 2001). Thus, according to the variation in eating habits among the lizards, it was possible to observe a difference in the thickness of muscle fibers in the muscle layer (Dehlawi and Zaher, 1989; Hamdi et al., 2014; Rodrigues-Sartori et al., 2011; Ahmed et al., 2009; Zaher et al., 2012).

Serotonin secreting cells (5-HT) are considered one of the major chemosensory cells of the GIT (Cheng et al., 2019). In the amphibian and reptile oesophagus these cells can be observed distributed along their epithelium, however in birds and mammals these are not reported, due to the epithelial change, from ciliated columnar pseudostratified epithelium to stratified squamous epithelium. In I. iguana was possible to observe the presence of 5-HT cells in the epithelium of the entire oesophagus like observed in all studies in reptiles, indicating that the presence of these cells does not depend on food habit.

In the gastric glands in the stomach, the 5HT cells, may have a role in stimulating gastrointestinal mucosa secretion, expansion of blood vessels and smooth muscle contraction, therefore accelerating the movement of the digestive tract (Wang et al., 2007). Despite being widely distributed in the stomach, the relative frequency may be different among reptiles. In I. iguana these were more frequent among the most developed glands in the cranial and medial parts of the stomach, as in Gekko japonicus (Huang and Wu, 2005). However, in Eumeces chinensis, Sphenomorphus indicus and Eumeces elegans (Huang and $\mathrm{Wu}, 2005$ ) and Takydromus wolteri (Lee and $\mathrm{Ku}, 2004$ ) these were more abundant in the caudal part. These data can be related to a phylogenetic approach, since the Lacertidae and Scincidae are closer to each other when compared to Iguanidae and Gekkonidae.

Many studies suggest that the distribution pattern of SSIR cells varies greatly in reptiles. SS has an inhibitory effect on the release of gastrin, thereby reducing stomach acid secretion (Friis-Hansen, 2007). Consequently, somatostatin exerts a potent suppressive effect on gastric emptying (Van Op den bosch et al., 2009). In the oesophagus of the green iguana, as well as the T. wolteri (Lee and $\mathrm{Ku}$, 2004) and E. kingii (Arena et al., 1990), SS-IR cells were not detected. However, in M. quinquetaeniata (El-Salhy and Grimelius, 1981) SS-IR cells were observed in the distal region of the oesophagus. In the stomach, SS-IR cells are predominant in the pylorus region in T. wolteri (Lee and Ku, 2004), E. chinensis, S. indicus and E. elegans (Huang and $\mathrm{Wu}, 2005$ ). These results are in accordance with those seen in I. iguana, whose SS-IR cells occupy the stomach glandular region near the intestine. It indicates an important function of SS-IR cells in gastric emptying.

\section{Conclusion}

In I. iguana, variation was observed in terms of the distribution of mucus secretions and the pattern of occurrence of serotonin and somatostatin-secreting enteroendocrine cells in the TGI, which possibly will result in an interspecific adaptive response.

\section{Acknowledgements}

We thank Unidade Integrada de Patologia Especializada (UnIPE) for allowing us to use the Aperio CS ${ }^{\mathrm{TM}}$ scanner to obtain the digital imagens present in this article. We thank Amanda Ribeiro Ricardo Brito for assistance with the laboratory techniques and article translation, besides great encouragement. We thank Beatriz Gouvea de Luca for help in the laboratory and encouragement in the construction of this article. 


\section{References}

AHMED, Y.A., EL-HAFEZ, A.A.E. and ZAYED, A.E., 2009. Histological and histochemical studies on the esophagus, stomach and small intestines of Varanus niloticus. Journal of Veterinary Anatomy, vol. 2, no. 1, pp. 35-48. http://dx.doi.org/10.21608/jva.2009.45136.

ALLEN, A. and SNARY, D., 1972. The structure and function of gastric mucus. Gut, vol. 13, no. 8, pp. 666-672. http://dx.doi. org/10.1136/gut.13.8.666. PMid:4562023.

ANDRADE, C.A.F., 2009. Iguana verde (Iguana iguana). Bicho da Vez, no. 6, pp. 1-3.

ARENA, P.C., RICHARDSON, K.C. and YAMADA, J., 1990. An immunohistochemical study of endocrine cells of the alimentary tract of the King's skink (Egernia kingii). Journal of Anatomy, vol. 170, pp. 73-85. PMid:2254171.

BANI, G., FORMIGLI, L. and CECCHI, R., 1992. Morphological observations on the glands of the oesophagus and stomach of adult Rana esculenta and Bombina variegata. Italian Journal of Anatomy and Embryology, vol. 97, no. 2, pp. 75-87. PMid:1285678.

BREUIL, M., SCHIKORSKI, D., VUILLAUME, B., KRAUSS, U., MORTON, M.N., CORRY, E., BECH, N., JELIĆ, M. and GRANDJEAN, F., 2020. Painted black: Iguana melanoderma (Reptilia, Squamata, Iguanidae) a new melanistic endemic species from Saba and Montserrat islands (Lesser Antilles).ZooKeys, vol. 926, pp. 95-131. http://dx.doi.org/10.3897/zookeys.926.48679. PMid:32336922.

CAKICI, Ö. and AKAT, E., 2013. Some histomorphological and histochemical characteristics of the digestive tract of the snake-eyed lizard, Ophisops elegans Menetries, 1832 (Squamata: lacertidae). North-Western Journal of Zoology, vol. 9, no. 2, pp. 257-263.

CHENG, X., VOSS, U. and EKBLAD, E., 2019. A novel serotonincontaining tuft cell subpopulation in mouse intestine. Cell and Tissue Research, vol. 376, no. 2, pp. 189-197. http://dx.doi. org/10.1007/s00441-018-02988-3. PMid:30666535.

DEHLAWI, G.Y. and ZAHER, M., 1989. Histochemical localization of carbohydrates in the mucosal epithelium of the alimentary tract of the skink Mabuya brevicollis. Journal of King Abdul Aziz University, vol. 1, no. 1, pp. 113-124. http://dx.doi.org/10.4197/ Sci.1-1.10.

DEHLAWI, G.Y. and ZAHER, M.M., 1985. Histological studies on the mucosal epithelium of the alimentary canal of the lizard Acanthodactylus boskianus (Family Lacertidae). Proceedings of the Zoological Society A.R. Egypt, vol. 9, pp. 67-90.

DÍAZ, A.O., GARCÍA, A.M. and GOLDEMBERG, A.L., 2008. Glycoconjugates in the mucosa of the digestive tract of Cynoscion guatucupa: A histochemical study. Acta Histochemica, vol. 110, no. 1, pp. 76-85. http://dx.doi.org/10.1016/j.acthis.2007.08.002. PMid:17945334.

ELLIOTT, J.R. 2007. Overview of reptile biology, anatomy, and histology. infectious diseases and pathology of reptiles. In: J.R. ELLIOTT, ed. New York: Taylor \& Francis Group, pp. 1-25.

EL-SALHY, M. and GRIMELIUS, L., 1981. The endocrine cells of the gastrointestinal mucosa of a squamate reptile, the grass lizard (Mabuya quinquetaeniata). A histological and immunohistochemical study. Biomedical Research, vol. 2, no. 6, pp. 639-658. http://dx.doi.org/10.2220/biomedres.2.639.

FALCÓN, W., ACKERMAN, J.D., RECART, W. and DAEHLER, C.C., 2013. Biology and Impacts of Pacific Island Invasive Species. 10. Iguana iguana, the Green Iguana (Squamata: iguanidae). Pacific Science, vol. 67, no. 2, pp. 157-186. http://dx.doi.org/10.2984/67.2.2.

FERRI, D., LIQUORI, G.E. and SCILLITANI, G., 1999. Morphological and histochemical variations of mucous and oxynticopeptic cells in the stomach of the seps, Chalcides chalcides. Journal of
Anatomy, vol. 194, no. 1, pp. 71-77. http://dx.doi.org/10.1046/ j.1469-7580.1999.19410071.x. PMid:10227668.

FERRI, D., LIQUORI, G.E., NATALE, L., SANTARELLI, G. and SCILLITANI, G., 2001. Mucin histochemistry of the digestive tract of the red-legged frog Rana aurora aurora. Acta Histochemica, vol. 103, no. 2, pp. 225-237. http://dx.doi.org/10.1078/0065-128100582. PMid:11368102.

FRIIS-HANSEN, L., 2007. Lessons from the gastrin knockout mice. Regulatory Peptides, vol. 139, no. 1-3, pp. 5-2. http://dx.doi. org/10.1016/j.regpep.2006.12.008. PMid:17234279.

GEORGE, L.L. and CASTRO, R.R.L., 1998. Histologia comparada. 2. ed. São Paulo: Roca, 286 p.

GUNDERSEN, H.J.G., 1977. Notes on the estimation of the numerical density of arbitrary profiles: the edge effect. Journal of Microscopy, vol. 111, no. 2, pp. 219-223. http://dx.doi. org/10.1111/j.1365-2818.1977.tb00062.x.

GUPTA, B.L., 1989. The relationship of mucoid substances and ion and water transport, with new data on intestinal goblet cells and a model for gastric secretion. Symposia of the Society for Experimental Biology, vol. 43, pp. 81-110. PMid:2701492.

HAMDI, H., EL-GHAREEB, A.W., ZAHER, M., ESSA, A. and LAHSIK, S., 2014. Anatomical, histological and histochemical adaptations of the reptilian alimentary canal to their food habits: II-Chamaeleon africanus. World Applied Sciences Journal, vol. 30, no. 10, pp. 13061316. http://dx.doi.org/10.5829/idosi.wasj.2014.30.10.82395.

HIRTH, H.F., 1963. Some apects of the natural history of Iguana iguana on a tropical strand. Ecology, vol. 44, no. 3, pp. 613-615. http://dx.doi.org/10.2307/1932553.

HUANG, X.G. and WU, X.B., 2005. Immunohistochemical study on gastrointestinal endocrine cells of four reptiles. World Journal of Gastroenterology, vol. 11, no. 35, pp. 5498-5505. http://dx.doi. org/10.3748/wjg.v11.i35.5498. PMid:16222743.

KARDONG, K.V., 2018. Vertebrates: comparative anatomy, function, evolution. 8th ed. New York: McGraw-Hill Education, pp. 504-545.

KIERNAN, J.A. 1990. Histological \& histochemical methods: theory and practice. 2nd ed. Frankfurt: Pergamon Press, $433 \mathrm{p}$.

KING, G., 1996. Reptiles and herbivory. London: Chapman \& Hall, pp. 29-42.

KOCA, Y.B. and GÜRCÜ, B., 2011. Morphological and histochemical investigations of esophagogastric tract of a lizard, Laudakia stellio (Agamidae, Linnaeus 1758). Acta Biologica Hungarica, vol. 62, no. 4, pp. 376-387. http://dx.doi.org/10.1556/ABiol.62.2011.4.4. PMid:22119867.

KUBIAK, M., 2019. Veterinary care of green iguanas (Iguana iguana) part 1: husbandry. Companion Animal, vol. 24, no. 7, pp. 386389. http://dx.doi.org/10.12968/coan.2019.0023.

LARA-LÓPEZ, M.D.S. and GONZÁLEZ-ROMERO, A., 2002 [viewed 15 September 2020]. Alimentación de la iguana verde Iguana iguana (Squamata: Iguanidae) en La Mancha, Veracruz, México. Acta Zoológica Mexicana [online], vol. 85, pp. 139-152. Available from: http://www.scielo.org.mx/scielo.php?script=sci_ arttext\&pid=S0065-17372002000100009\&lng=es\&nrm=iso

LEE, H.S. and KU, S.K., 2004. An immunohistochemical study of endocrine cells in the alimentary tract of the grass lizard, Takydromus wolteri Fischer (Laceridae). Acta Histochemica, vol. 106, no. 2, pp. 171-178. http://dx.doi.org/10.1016/j. acthis.2003.10.008. PMid:15147638.

LEE, J.H., KU, S.K. and LEE, H.S., 1999. An immunohistochemical study of endocrine cells in the alimentary tract of the snake, Rhabdophis tigrinus tigrinus. Korean Journal of Veterinary Research, vol. 39, no. 4, pp. 689-697. 
LILLIE, R.D. and FULLMER, H.M., 1976. Histopathologic technic and practical histochemistry. 4th ed. New York: McGraw-Hill, pp. 559-610.

LOO, S.K. and WONG, W.C., 1975. Histochemical observations on the mucins of the gastrointestinal tract in the toad (Bufo melanostictus). Cells, Tissues, Organs, vol. 91, no. 1, pp. 97-103. http://dx.doi.org/10.1159/000144374. PMid:1136708.

LUPPA, H., 1977. Histology of the digestive tract. In: C. GANS and T.S. PARSONS, eds. Biology of the Reptilia. New York: Academic Press, vol. 6, pp. 225-313.

MACHADO-SANTOS, C., ZECA, S.G., ABIDU-FIGUEIREDO, M., RIBEIRO, I. and SALES, A., 2011. The esophagus of the crocodilian Caiman latirostris (Reptilia, Crocodylia): histological, histochemical and immunohistochemical study. Journal of Morphological Sciences, vol. 28, no. 2, pp. 113-119.

MASYITHA, D., MAULIDAR, L., ZAINUDDIN, Z., SALIM, M.N., ALIZA, D., GANI, F.A. and RUSLI, R., 2020. Histology of watersnake (Enhydris Enhydris) digestive system. E3S Web of Conferences, vol. 151, 01052. http://dx.doi.org/10.1051/e3sconf/202015101052.

O'MALLEY, B., 2005. Clinical anatomy and physiology of exotic species. New York: Elsevier, pp. 57-75. https://doi.org/10.1016/ B978-0-7020-2782-6.X5001-7.

PIANKA, E.R. and VITT, L.J., 2003. Lizards: windows to the evolution of diversity. Berkeley: University of California Press, pp. 141-170.

RICKLEFS, R.E., 2003. A economia da natureza. Rio de Janeiro: Guanabara-Koogan, 503 p.

RODRIGUES SARTORI, S.S., NOGUEIRA, K.O.P.C., ROCHA, A.S. and NEVES, C.A., 2011. Morphology of the stomach of the tropical house gecko Hemidactylus mabouia (Squamata: gekkonidae). Acta Zoologica, vol. 92, no. 2, pp. 179-186. http://dx.doi. org/10.1111/j.1463-6395.2010.00451.x.

RODRIGUES-SARTORI, S.S., NOGUEIRA, K.P.O.C., ARAÚJO, V.A. and NEVES, C.A., 2015. Functional morphology of the esophagus of the tropical house gecko Hemidactylus mabouia (Squamata: gekkonidae). Animal Biology, vol. 65, no. 2, pp. 177-191. http:// dx.doi.org/10.1163/15707563-00002469.

ROVIRA, J., VILLARO, A.C., BODEGAS, M.E., VALVERDE, E. and SESMA, P., 1993. Structural study of the frog Rana temporaria larval stomach. Tissue E Cell, vol. 25, no. 5, pp. 695-707. http:// dx.doi.org/10.1016/0040-8166(93)90051-L. PMid:8296308.

RYU, G.R., LEE, E., KIM, J.J., MOON, S.D., KO, S.H., AHN, Y.B. and SONG, K.H., 2018. Comparison of enteroendocrine cells and pancreatic $\beta$-cells using gene expression profiling and insulin gene methylation. PLoS One, vol. 13, no. 10, pp. e0206401. http:// dx.doi.org/10.1371/journal.pone.0206401. PMid:30379923.

SANTOS, C.M., NASCIMENTO, A.A., PERACCHI, A.L., SALES, A., MIKALAUSKAS,J.S. and GOUVEIA, S.F., 2008. Immunocytochemical study of gastrintestinal endocrine cells in insectivorous bats (Mammalia: chiroptera). Brazilian Journal of Biology = Revista Brasileira de Biologia, vol. 68, no. 3, pp. 663-669. http://dx.doi org/10.1590/S1519-69842008000300026. PMid:18833490.

SCHONHOFF, S.E., GIEL-MOLONEY, M. and LEITER, A.B., 2004. Minireview: development and differentiation of gut endocrine cells. Endocrinology, vol. 145, no. 6, pp. 2639-2644. http://dx.doi. org/10.1210/en.2004-0051. PMid:15044355.

SMITH, D., DOBSON, H. and SPENCE, E., 2001. Gastrointestinal studies in the green iguana: technique and reference values. Veterinary Radiology E Ultrasound, vol. 42, no. 6, pp. 515-520. http:// dx.doi.org/10.1111/j.1740-8261.2001.tb00979.x. PMid:11768518.
SOLCIA, E., CAPELLA, C., VASSALLO, G. and BUFFA, R., 1975. Endocrine cells of the gastric mucosa. International Review of Cytology, vol. 42, pp. 223-286. http://dx.doi.org/10.1016/ S0074-7696(08)60982-1. PMid:53215.

SPINNER, L., 2018 [viewed 5 August 2020] Caring for the green iguana. Reptiles Magazine [online]. Available from: https:// www.reptilesmagazine.com/caring-for-the-green-iguana/

TELES, D.A., BRITO, S.V., TEIXEIRA, A.A.M., RIBEIRO, S.C., ARAUJOFILHO, J.A., LIMA, V.F., PEREIRA, A.M.A. and ALMEIDA, W.O., 2017. Nematodes associated with Iguana iguana (Linnaeus, 1758) (Squamata, Iguanidae) in Semi-arid areas of Northeastern Brazil. Brazilian Journal of Biology $=$ Revista Brasileira de Biologia, vol. 77, no. 3, pp. 514-518. http://dx.doi.org/10.1590/15196984.17615. PMid:27683813.

THONGBOON, L., SENARAT, S., KETTRATAD, J., JIRAUNGKOORSKUL, W., WANGKULANGKUL, S., POOLPRASERT, P., PARA, C., KANEKO, G. and PENGSAKU, T., 2019. Gastrointestinal tract and accessory organs in the spotted bent-toed gecko, Cyrtodactylus peguensis (boulenger, 1893): a histological and histochemical study. Journal of Morphological Sciences, vol. 36, no. 4, pp. 223-230. http://dx.doi.org/10.1055/s-0039-1693021.

TOWNSEND, J.H., SLAPCINSKY, J., KRYSKO, K.L., DONLAN, E.M. and GOLDEN, E.A., 2005. Predation of a Tree Snail Drymaeus multilineatus (Gastropoda: Bulimulidae) by Iguana iguana (Reptilia: Iguanidae) on Key Biscayne, Florida. Southeastern Naturalist, vol. 4, no. 2, pp. 361-364. http://dx.doi. org/10.1656/1528-7092(2005)004[0361:POATSD]2.0.CO;2.

TROYER, K., 1984. Structure and function of the digestive tract of a herbivorous lizard Iguana iguana. Physiological Zoology, vol. 57, no. 1, pp. 1-8. http://dx.doi.org/10.1086/physzool.57.1.30155960.

TSCHANZ, S.A., BURRI, P.H. and WEIBEL, E.R., 2011. A simple tool for stereological assessment of digital images: the STEPanizer. Journal of Microscopy, vol. 243, no. 1, pp. 47-59. http://dx.doi. org/10.1111/j.1365-2818.2010.03481.x. PMid:21375529.

UETZ, P., FREED, P. and HOŠEK, J., eds. 2020 [viewed 19 May 2020]. The Reptile Database [online]. Available from: http://www. reptile-database.org

VAN OP DEN BOSCH, J., ADRIAENSEN, D., VAN NASSAUW, L. and TIMMERMANS, J.P., 2009. The role(s) of somatostatin, structurally related peptides and somatostatin receptors in the gastrointestinal tract: a review. Regulatory Peptides, vol. 156, no. 1-3, pp.1-8. http://dx.doi.org/10.1016/j.regpep.2009.04.003. PMid:19362110.

VIRGILIO, F., SCIARRILLO, R., DE FALCO, M., LAFORGIA, V., CAVAGNUOLO, A. and VARANO, L., 2004. Seasonality in thyroid function in chalcides ocellatus (reptilia, scincidae). The Italian Journal of Zoology, vol. 71, no. 2, pp. 53-57. http://dx.doi. org/10.1080/11250000409356606.

WANG, S.H., DONG, L., LUO, J.Y., GONG, J., LI, L., LU, X.L. and HAN, S.P., 2007. Decreased expression of serotonin in the jejunum and increased numbers of mast cells in the terminal ileum inpatients with irritable bowel syndrome. World Journal of Gastroenterology, vol. 13, no. 45, pp. 6041-6047. http://dx.doi. org/10.3748/wjg.v13.45.6041. PMid:18023097.

ZAHER, M., EL-GHAREEB, A.W., HAMDI, H., ESSA, A. and LAHSIK, S., 2012. Anatomical, histological and histochemical adaptations of the reptilian alimentary canal to their food habits: I. Uromastyx aegyptiaca. Life Science Journal, vol. 9, pp. 84-104.

ZUG, G.R., VITT, L.J. and CALDWELL, J.P., 2001. Herpetology: an introductory biology of amphibians and reptiles. 2nd ed. San Diego: Academic Press, pp. 123-146. 